\title{
Micro-Teaching Experiences in a Pre-Service Early Childhood Education Programme
}

\author{
Florence Undiyaundeye, Agbama Inakwu A. \\ Federal College of Education, Obudu, Cross River State, Nigeria
}

\begin{abstract}
Microteaching has been widely used in preservice teacher education programme to enhance prospective teachers' instructional experiences. In Early Childhood Education Programme, the use of microteaching offers valuable opportunities for trainee-teachers to develop effective strategies. Understanding the perceptions and concerns of female students teachers is crucial for promoting teacher education programmes' outcome. This study is aimed at investigating the responses of sixty-one female teacher trainees from the Early Childhood Education (ECE) programme in the School of Education, Federal College of Education, Obudu, Cross River State, Nigeria (FCECRS), regarding the microteaching component offered in two courses of ECE teaching methods. A combination of quantitative and qualitative techniques was employed for the purpose of collecting the data. A questionnaire and a focus group interview were used as the main tools for data collection. The findings show that prospective teachers described a variety of benefits they gained from microteaching experience. Recommendations were also drawn.
\end{abstract}

\section{Introduction}

Is pre-service training necessary? This is the title of an article by David Gordon [21]. In this article, the author argues that teachers are born and not made as such it does not make sense to establish a teacher training institutions which is to be trusted with the task of preparing teachers. Longwell [27] effectively demolishes this notion. He contends that the idea that a person is exclusively fit for a particular profession is an illusion and that the born teacher may be born for teaching in one situation and do not nearly do well in another situation. There is no doubt however that the notion of the "natural teacher" especially at the secondary level held sway for long in many countries. In England, for example, it was believed for long that the secondary school teacher was sufficiently equipped by sound moral character and a good knowledge of his subject [20].

It is gratifying, however, that the need for training courses for teachers is now universally accepted. All over the world, the value of instruction depends to a large extent, on the quality and quantity of professional trainee teachers. Indeed teachers are the lifelines of the sound educational system of any nation. If the quality of education is shaken, it is usually not uncommon to point accusing fingers at teachers.

Micro-teaching is one of the most recent innovations in teacher education programme which aims at modifying teachers behaviour according to modified objects. Education enterprises in the country has recently recognized the importance of micro-teaching in preparing classroom teachers. Micro-teaching is one of those innovative ideas which has been used, in recent years, to improve classroom teaching.

According to Woodel [42] the history of microteaching dates back to 1961 when Adeson a doctoral candidate at Standard University discovered the use of video tape recorder for teaching in an innovative teacher education programme.

Since then a number of researchers have undertaken to test the usability and applicability of video tapes and other teaching aids to modify student - teacher behaviour in training programmes. It will not be out of context that in USA almost all teachers training colleges and programmes use microteaching in modifying teacher behaviour. Amobi [4] supported the view that microteaching, as a preservice teaching laboratory experiment, should be included in teacher education.

This paper highlighted the salient benefits of microteaching, as prospective teachers perceive them. It was also the purpose of this paper to show that microteaching has the potential to impact trainee teachers ${ }^{e e}$ beliefs and attitudes. Within the traditional theory/practice dichotomy, there has always been an assumption that student teachers will be able to transfer the pedagogical theories and approaches they learned in colleges of education to their future classes in school [26], [18, [27]. However, a formal practical training, such as the use of microteaching, may assist in bridging the gap between theory and practice. A micro teaching programme provides preservice teacher- trainees with a simulated situation to put the theories that they have learned into practice and to develop confidence and teaching skills while conducting a mini-lesson to their colleagues. Microteaching is also intended to provide teacher trainees with additional practical experience before they start their clinical practice in real classes. The original model was cyclical in nature since it involved ,plan, teaching observe, critique ${ }^{\text {ee }}$ followed 
by the repetition of the same steps after the whole process was reviewed [7], [4]. The microteaching model was found to help student teachers learn about and reflect upon different teaching procedures that they have been exposed to in the methods of teaching classes. Some students consider microteaching as „fake teachingee since it does not involve real students in a real teaching situation where a teacher and students interact naturally. Bell [7] argues that microteaching provides students with valuable teaching experiences and made them aware of the benefits and relationships between theories and practice.

Researchers recommend searching for and adopting applications and experiences that provide female student teachers with opportunities to be involved in exploring pedagogical experiences, self reflection and critical analysis of teaching [17]; [36]. [22] indicates that such opportunities allow female student teachers to experiment with aspects of practice and then learn from that experience. Microteaching application is considered a suitable approach to meet the above-mentioned recommendations. In the present study, the microteaching application in the two methods of teaching courses was designed to provide students with practical experiences after they had been exposed to different approaches and techniques for teaching Early Childhood Education (ECE) classes. It was therefore, intended to prepare students for their ,practice teachingee in primary schools. By conducting microteaching, students would try the skills they learned with their colleagues before they starte using them in real classes. The microteaching component along with the lesson planning and selfreflection made up $30 \%$ of the students ${ }^{\text {ee }}$ course grade.

Microteaching application has gained popularity as a practical training tool in pre-service teacher education programmes. Ever since its emergence in the 1960s, the practice of microteaching has spread rapidly in different parts of the world, including the Middle East. In the present pre-service ECE teacher education programme in the School of Education, Federal College of Education, Obudu, Cross River State, Nigeria, it makes up about $30 \%$ of the total time and grade of all methods of teaching courses. In those courses students have to plan and conduct mini-lessons to their peers, self-reflections and giving feedback are integral components of the microteaching practice. A number of female student teachers are to enjoy this experiment while others struggle to get through the whole process of practicing to learn how to teach. Hence, it is vital to conduct a thorough investigation to find out about

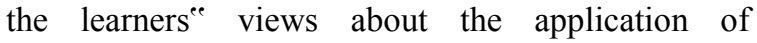
microteaching in their programme of study. Ultimately, the findings of this study will assist course instructors to review the programme and meet students ${ }^{\text {ee }}$ needs and expectations.

\section{Research Questions}

The following research questions will guide the study:

1. How do early childhood female student teachers view microteaching in relation to their managerial and preparational skills?

2. What kind of attitude or feeling do female student teachers hold about the practice of microteaching?

3. Methodology

The subjects of this study were Seventy-eight (78) female prospective early childhood education teachers enrolled in two different courses of teaching methods of early childhood in the School of Education, Federal College of Education (FCE) Obudu. However, seventeen were excluded from the results because they were absent on the day the questionnaire was administered. Thirty students from teaching methods of Social Studies to Nursery learners (Nur) participated in the study while thirtyone students from the teaching methods of Social Studies in Primary schools (Pri). The first course (Nur) was a prerequisite for the second one (Pri) at the time of the study. The researchers taught one of the two sections from each course while the other two sections were taught by two other females. In each course, each student was required to prepare a twenty minute mini-lesson, teach it to their peers and reflect orally and in writing about their experiences in conducting that lesson. The overall weight of the microteaching component made up about $30 \%$ of each course grade organized into two themes in accordance with the purpose and research questions of the study. The questionnaire was developed and referred by a number of colleges of education teachers including Early Childhood Education specialists in the School of Education in FCE Obudu in order to establish its validity. It used a five-point likert scale extending from five (SA) to one (SD). The Cronbach Alpha formula was used to compute the reliability of the questionnaire and the value was found to be 0.91 .

\section{Data Collection}

Data were collected using 18 items questionnaires to answer the research questions. These data were collected toward the end of 2009/2010 from female student teachers in two courses of teaching methods of Early Childhood (Teaching method of ECE) to nursery learners and teaching methods of ECE to primary studies in the School of Education Federal College of Education, Obudu. The reason for conducting the study near the end of the semester is that by that time students would have finished all 
their mini-lesson sessions and they would have gone through all the microteaching experience (for the female teachers in the department of Early Childhood Education in the School of Education, Federal College of Education, Obudu) in both courses. Each course included two sections, one taught by the researchers. 18 questions (9 Nur and Pri. 9) were distributed to students in the four sections during lecture period and collected from all participating students on the same day.

After conducting the questionnaire with students in the four sections, focus group interview sessions were organized and conducted by the researchers with the help of some students in each section. Only students in the two sections taught by the researchers participated in the focus group interview. The reason for choosing these two sections is that all students from two sections participated in the questionnaire (Nur. 9 And Pri. 9)

An intensive training session had been conducted to all group leaders to explain how to conduct the interview with their colleagues. The reasons for involving students in the interviewing their peers was that prospective teachers were expected to be more open and speak more freely if they were interviewed by their colleagues. All interviews were conducted over two classes in each section in order to give the researchers enough time to monitor the work of the group leaders.

\section{Data Analysis}

Both quantitative and qualitative data analyses were conducted in order to better the understanding of the students ${ }^{\text {ee }}$ perspectives regarding microteaching applications in the two courses of methods of teaching Early Childhood Education (ECE). In order to analyze the quantitative data collected by the five-point likert scale questionnaire, the statistical Package for Social Science (SPSS) programme was utilized to obtain different types of descriptive statistics and independent sample t-test.

A qualitative data analysis technique was used to interprete the data collected via the focus-group interviews, specifically the content analysis method (ROS, 1989).

\section{Data Presentation}

Research Question I: How do ECE female student view microteaching in relation to their managerial and preparation skills?
Table 1. Preparation and Managerial Skill

\begin{tabular}{|l|c|c|c|c|c|}
\hline \multicolumn{1}{|c|}{ Items } & $\begin{array}{c}\text { Total } \\
\text { mean }\end{array}$ & $\begin{array}{c}\text { Mean } \\
\text { Nursery }\end{array}$ & Primary & $\begin{array}{c}\text { t- } \\
\text { test }\end{array}$ & Sign \\
\hline Microteaching: & 4.51 & 4.53 & 4.48 & - & - \\
\hline $\begin{array}{l}\text { Helped me to } \\
\text { organize my } \\
\text { time }\end{array}$ & 4.51 & 4.57 & 4.45 & - & - \\
\hline $\begin{array}{l}\text { Helped me to } \\
\text { learn how to } \\
\text { manage the } \\
\text { class }\end{array}$ & 4.50 & 4.55 & 4.45 & - & - \\
\hline $\begin{array}{l}\text { Offered me a } \\
\text { practical } \\
\text { opportunity to } \\
\text { teach a lesson }\end{array}$ & 4.57 & 4.60 & 4.55 & - & - \\
\hline $\begin{array}{l}\text { Give me an } \\
\text { opportunity to } \\
\text { improve my } \\
\text { lesson } \\
\text { planning }\end{array}$ & 4.59 & 4.60 & 4.58 & - & - \\
\hline $\begin{array}{l}\text { Helped me } \\
\text { write good } \\
\text { performance } \\
\text { objectives and } \\
\text { material }\end{array}$ & 4.66 & 4.67 & 4.65 & - & - \\
\hline \hline $\begin{array}{l}\text { Helped me } \\
\text { learn how to } \\
\text { predict } \\
\text { classroom } \\
\text { problems me }\end{array}$ & 4.07 & 4.07 & 4.07 & - & - \\
\hline $\begin{array}{l}\text { Helped me } \\
\text { learn to use } \\
\text { technology } \\
\text { appropriately }\end{array}$ & 4.28 & 4.33 & 4.23 & - & - \\
\hline
\end{tabular}

The analysis of question I result demonstrated that student teachers felt that microteaching experiences assisted them to enhance both managerial and preparation skill. The mean 104 scores for the variable concerning the development of materials were 4.66 for the first group (Nur) and 4.67 for the second group (Pri). These close high mean scores demonstrated the positive impact of microteaching on students ${ }^{\text {ee }}$ views about their teaching competency. Also the total mean scores for „lesson planning and writing performance objectives ${ }^{\text {ee }}$ (4.57 and 4.59) clearly demonstrated that students felt that conducting a mini-lesson provided them with valuable experience to learn to write comprehensible lesson plans and performance outcomes. These results highlighted the importance of microteaching in providing students with opportunities to try to apply the teaching strategies that they learned in different courses. They also demonstrated studentse eagerness to see how the theories can work for them when they practice the craft of teaching. According to Agbama et al [6] evidence that prospective teachers thought that microteaching was a worthwhile learning experience because it helps them bridge the gap between theory and practice.

\section{Research Question Two (2)}

States thus: What kind of attitude or feeling do female student teachers hold about the practice of microteaching? 
Table 2. Attitudes and personal feeling

\begin{tabular}{|l|l|l|l|l|l|}
\hline \multicolumn{1}{|c|}{ Items } & $\begin{array}{c}\text { Total } \\
\text { mean }\end{array}$ & $\begin{array}{c}\text { Mean } \\
\text { Nurs } \\
\text { ery }\end{array}$ & $\begin{array}{c}\text { Primar } \\
\mathbf{y}\end{array}$ & t-test & Sign \\
\hline $\begin{array}{l}\text { Microteac } \\
\text { hing: }\end{array}$ & 3.66 & 3.63 & 3.68 & -148 & .883 \\
\hline $\begin{array}{l}\text { Was } \\
\text { carried } \\
\text { out in an } \\
\text { Artificial } \\
\text { environm } \\
\text { ent }\end{array}$ & 2.18 & 3.37 & 3.66 & 1.217 & .229 \\
\hline $\begin{array}{l}\text { Result in } \\
\text { neglective } \\
\text { key } \\
\text { activities } \\
\text { in the } \\
\text { method } \\
\text { course }\end{array}$ & 3.26 & 1.93 & 3.29 & -737 & .847 \\
\hline $\begin{array}{l}\text { Consume } \\
\text { d a lot of } \\
\text { my time }\end{array}$ & 2.05 & 2.57 & 3.16 & -1.913 & .061 \\
\hline $\begin{array}{l}\text { Made me } \\
\text { feel bored }\end{array}$ & 2.90 & 3.37 & 2.16 & -1.591 & .117 \\
\hline $\begin{array}{l}\text { Forced me } \\
\text { to do } \\
\text { difficult } \\
\text { task }\end{array}$ & 3.61 & 2.47 & 3.23 & -1.563 & .123 \\
\hline $\begin{array}{l}\text { Was time } \\
\text { limited } \\
\text { and } \\
\text { controlled }\end{array}$ & 2.72 & 3.37 & 3.84 & -2918 & .005 \\
\hline $\begin{array}{l}\text { Made me } \\
\text { feel } \\
\text { embarrass } \\
\text { ed when } \\
\text { teaching } \\
\text { my } \\
\text { colleagues }\end{array}$ & 3.51 & 2.47 & 2.97 & -3.869 & .006 \\
\hline $\begin{array}{l}\text { Forced me } \\
\text { to think of } \\
\text { the } \\
\text { evaluation } \\
\text { criteria } \\
\text { while } \\
\text { planning }\end{array}$ & 3.51 & 3.07 & 3.94 & -3.86 & .006 \\
\hline $\begin{array}{l}\text { Forced me } \\
\text { to think of } \\
\text { evaluation } \\
\text { while } \\
\text { teaching }\end{array}$ & 3.31 & 2.70 & 3.90 & 3.89 & .000 \\
\hline
\end{tabular}

Table 2 showed two main significant results relevant to studentse concerns about their microteaching task evaluation. These two results indicated that students continually think about the grades that supervisors would give for their performance in the mini-lesson.

The mean scores for their concerns about „lesson planning assessment" were 3.07 for the first group (Nur.) and 3.94 for the second group (Pri) while the mean scores for their concerns about „mini lessons evaluation were 2.70 and 3.90 for the first and second group respectively. The significant differences in these results highlight the students" anxiety and the amount of time they spent in thinking about microteaching assessment during the process of planning and executing their mini lesson. These significant results might also be interpreted in relation to student teachers" preconceptions about their teaching and/or language competence and their microteaching grades.

The number of years they spent in the programme and their experiences with microteaching might have contributed to the significance difference in the view of the two groups about lesson planning assessment ${ }^{\text {te }}$ and mini-lessons evaluation. Generally, students bring their academic experience and expectations to the classroom and they are to some extent, expecting teachers to comply with them. Apparently, educators and teachers trainers should try to understand what preconceptions student teachers bring with them to their microteaching experiences in order to help them acquire essential instructional knowledge and enhance effective teaching technique [12].

\section{Recommendations}

The result of this study emphasized certain key elements about the application of microteaching experience in pre-service teacher training programs. Hence, a few suggestions and implications may be discussed within the framework of those results.

1. The microteaching component should continue to be integrated with courses of teaching methods of ECE in pre-service teacher education programs in college and/or universities. The logic for its inclusion is that the micro teaching experience is highly appreciated by a number of student teachers taking the methods of teaching ECE courses.

2. More microteaching sessions should be organized and aligned with different teaching strategies and/or language skills.

3. Teacher trainers and educators should pay more attention to students" views and concerns regarding their performance assessment for executing mini lessons. Students usually posses some preconceptions about the art of teaching and the methods of evaluation because those students have been sitting in classes for more than 14 years observing teachers using a variety of teaching methods to teach them.

4. More research work is needed to look at issues highlighted by the results such as the issue of assessing students teachers ${ }^{\text {ee }}$ performance during microteaching sessions.

5. More fund should be made available for this innovation.

\section{Conclusion}

This study examined the impact of microteaching experiences on the views of prospective teachers in an ECE pre-service education program. It mainly focused on the salient concepts that emerged as a result of executing mini-lessons to colleagues in simulated situations. A mixture of quantitative and qualitative approaches were utilized to collect relevant data from two groups of ECE teachers 
trainees who were taking two different courses in teaching methods of ECE. The overall results of this study demonstrated that the inclusion of microteaching in teacher training program is viewed to have positive impact on ECE student teachers awareness and views regarding their language and teaching competencies. The data provided clear evidence that prospective teachers appreciated the beneficial experiences of microteaching in developing effective instructional strategies. The overwhelming benefits of microteaching justify the use of why it is well-liked by prospective teachers.

A significant result highlighted student ${ }^{\text {ee }} \mathrm{s}$ concern about the issue of assessing their microteaching performance. The findings stressed the need for conducting further studies to investigate the issue of assessing students ${ }^{\text {ee }}$ performance during microteaching sessions. Future studies should specifically focus on students ${ }^{\text {ee }}$ preconceptions and/or predetermined criteria for assessing microteaching experiences in ECE teacher education programs.

\section{References}

[1] N.A Ada \& J.O Eriba Organization and implementation of students teaching practice exercise. In Akinmade et al (eds) improving Teacher Education in the 21st century. Nigeria: challenges and strategies Jos: Department of Arts and Social Science Education. University of Jos. (2000)

[2] D.W, Allen. Microteaching: A personal view. Massachusetts. Addissin Wesley (1980)

[3] S, Akalin. Comparison between traditional teaching and microteaching during school experience of students teacher. Eurasian journal of education research (2005) 20 $1-13$

[4] F.A. Amobi Pre-service teachers reflectivity on the microteaching experience. Teacher education quarterly (2005) 32 (1) $115-128$

[5] F.A Amobi and L. Irwin Implementing on campus microteaching to elicit pre-service teachers reflection on teaching action. Fresh perspective on an established practice. Journal of the scholarship of teaching and learning (2009) (1) $27-34$

[6] L. Author, Esp studente view of ESL grammar learning. GAMA online Journal of language studies (2010) $10(3)-156$

[7] N. Bell. Microteaching: What is $G$ that is going on here? Linguistics and education (2007) $1824-40$ [8] J. Benton - Isupper The microteaching experience. Students perspective. Education (2001) 121 (4) 830 - 835

[9] F.S, Bolin, J,M. Falk. The teachers as curriculum decision maker. Colombia: Teachers College Press (1980)

[10] Britton, I.R and Anderson K.A. Peer coaching and pre-service teaches examining and underutilized concept. Teaching and teacher education (2010)
[11] B. Buch, Perspective on Educational Change. Appleton: Century Craft. (1980)

[12] A. Butler. Pre-service music teacher conceptions of teaching effectiveness microteaching experience and teaching performance. Journal of research in music education (2001) 49 (3) $258-272$

[13] J.W. Creswell. Research design: qualitative, quantitative and mixed methods approaches. Thousand oaks' C.A sage publications. (2003)

[14] D.R Cruickshank, et al. Preparing Americans teachers, Bloomington W: Phi Delta Kappa (1996)

[15] N Denzin and Y. Lincoln (Eds). Handbook of qualitative research. Thousand oaks C.A Sage publications (1994)

[16] S. Feiman -Nemser. From preparation to practice. Designing a continuum to strengths and sustain teaching. Teachers college record (2010) 103 (6) 1013 - 1055

[17] M.L. Fernandez. Investigating toward what prospective teachers learn through microteaching lesson study. Teaching and teacher education (2010) 26 (2) 351 362

[18] M.L. Fernandez and M. Robinson. Prospective teacherse perspectives on microteaching lesson study. Education (2007) 127 (2) $203-215$

[19] J.M Fry and Communication. Interactive learning environment 14 (3) 193 - 204

[20] R. Goodthings, M. Bryan \& Meparttean (eds) Changing priorities in Teacher Education. London. Published on Behalf of the British Comparative Education Society by Groomhelm Ltd (1982)

[21] D. Gordon. Is Pre-service Training really necessary? British journal of teachers education, (1980) 6 (2), pp. 2025

[22] P Grossman and M McDonald. Back to the future: Direction for reach in teaching and teacher education (2008)

[23] A. Higgins and H. Nicholl. The experience of lectures and students in the use of microteaching as a teaching strategy. Nurse Education in Practice (2003) 26 (8) 1530 1543

[24] J.Y. Hong. Pre-service and beginning teacherse professional identity and to relation to dropping out of the profession. Teaching and teacher education (2010) 26(8) $1530-1543$

[25] A.T Isarckay and S. Sanli. The effect of microteaching application on the pre-service teachers competency levels. Procedure social and behavioural sciences (2009) 1 (1) $844-847$ 
[26] F. Isubulscu. Congruence and dissonance between microteaching and macro-teaching. Procedia social and behavioural sciences (2010) 2 (2) 326 - 329

[27] K.E. Johnson. The sociaculture turn and its challenges for second language teacher education TESOL quarterly, (2006) 40. 235 - 257

[28] B. Joyee Conceptions of man and their implication for teachers education. London: Mitzel H.E. (1995)

[29] A. Langeveld. The Psychology of Teachers and the teaching profession. In the education and training of teachers your book of education. Evans brother Limited (1963)

[30] H.L. Lu. Research on peer coaching in pre-service teacher education: A review of literature teaching and teacher education (2010) 26748 - 753

[31] R.J. McDonald Behaviour modification in teacher education. London Reinemann (1973)

[32] O. McNamara, L. Roberts, T. Basil and T. Brown. Rites of passage in initial teacher training ritual performance. Ordeal and numeracy skill test. British education research Journal (2002) 28 (6) $863-878$

[33] M.C. Ogeyik. Attitudes of the student teachers in English language teaching programs towards microteaching technique. English language teaching (2009) 2 (3) 205 - 212

[34] A. Oliver. Curriculum improvement New York: Dodd means and company. (1965)

[35] M.Q. Patton. Qualitative research evaluation methods (3rd ed). Thousand oats publication, Inc (2002)

[36] R.T. Putman \& H. Borko. What do new views for knowledge and thinking have to say about research on teacher learning educational research (2000) 29 (1) 4 - 15

[37] D.D. Ross. First Steps in developing a reflective approach. Journal of teacher education (1989) $4022-30$

[38] G. Saferoglu. Teacher candidates" reflections on some components of a pre-service English teacher education program in Turkey. Journal of education for teaching (2006) 32 (4) $369-378$

[39] K. Subramaniam. Creating a microteaching evaluation form: the needed evaluations criteria education. (2006) 126 (4) $666-677$

[40] G. Wilkinson. Enhancing microteaching through additional feedback from pre-service administrators. Teaching and teacher education (1996) 12 (2) 211 - 221

[41] S. Yaman . Conceptual change of pre-service teachers. a longitudinal action reach study in ELT. Procedia social and behaviour sciences (2010) 3, 227 - 237

[42] H.G. Wood "education for uncertain Futures" World Future Bulletin (1981) (Sept/Oct 1981)
[43] R.H Young. Teaching in a world of change. Port Harcourt: Brace and World Inc. NY American Educational Research Journal (1976) 4th/8th - 205. 